\title{
Impact of Government Debt on Economic Growth in Kenya: A Critical Literature Review
}

\author{
Silveria Mukwandiga Murungi \\ Dr. Kennedy Okiro \\ University Of Nairobi, Kenya
}

Doi: 10.19044/esj.2018.v14n1p240 URL:http://dx.doi.org/10.19044/esj.2018.v14n1p240

\begin{abstract}
The study examined the impact of government debt on economic growth through extensive review of relevant theoretical and empirical literature. Governments borrow to cover budget deficits. The debt is obtained either from the domestic market or from external sources. Government debt by Greece proved to be bad for the economy while government debt by USA which has the highest debt in the world proved to be manageable. This led to the need to examine the impact of government debt on economic growth in Kenya. The major theories examined included Adolph Wagner's law of increasing state activity, the debt overhang theory, crowding out theory and the Ricardian equivalence theory. The main objective of the critical literature review was to review the literature done on the impact of government debt on economic growth while the specific objectives were to examine the impact of government debt on economic growth, to investigate the effects of macroeconomic variables on the relationship between government debt and economic growth, to establish the effects of regulatory reforms on the relationship between government debt and economic growth, and to review the joint effect of macroeconomic variables and regulatory reforms on government debt and economic growth. The majority of the findings from the literature reviewed on government debt indicated that there was an impact of government debt on economic growth; some showed a positive economic growth while others showed a negative economic growth.
\end{abstract}

Keywords: Economic growth, government debt, public finances, Kenya

\subsection{INTRODUCTION}

\subsection{Background of the Study}

One method of financing government operations is through debt. Government borrows so as to minimize gap on investment and savings (Likita, 2010). The government may borrow from either the domestic market or the 
external market. Government debt may have an impact on macroeconomic variables such as inflation, exchange rates, unemployment, interest rates and money supply. It also may have an impact on the economic growth of the country. When the government borrows heavily from the domestic market, there may be crowding out where the financiers are not left with enough funds to advance to the private sector. This will in turn cause the interest rates to go up. On the other hand if it borrows from the external market, the exchange rate will be affected as foreign exchange is required to pay for the interest and principle (Saheed, 2015). These have an effect on unemployment as the private sector, because of crowding out may not be able to create more wealth which may result in retrenchments or suspension of employment and the government may not be able to employ because it will use most of its resources for paying the principle and interest (Khan, Khanwar, \& Khan 2014). Loans advanced by banks cause creation of money which in turn may cause inflation (Nyalihama, 2011).

There has been a growing concern in Kenya in regard to the increase in government debt in recent times. There has been a growing appetite for the domestic indebtedness while the external debt has been on the rise. The interest rates have been on the upward trend while the Kenya shilling has been weakening to the major currencies and inflation is high (Muthui, Kosimbei, \& Thuku, 2013). It is this in mind that this critical literature review would like to review the work done by other researchers on the impact of government indebtedness on economic growth in Kenya.

\subsubsection{Government Debt}

Governments the world over have been financing their budget deficit through debt financing. The debt could be attained through funds from the domestic market or the external market. Reducing the gap between investment and savings is the main reason why the governments borrow (Likita, 2010). Real levels of needed domestic savings for investment and actual investment are created by absence of adequate savings. Mechanism where savings translate itself into investment does not exist where savings is low and government must make an effort to remove such gap. Scarce internal capital formation due to repeated circle of low productivity, low savings and low income are symbols of developing countries in Africa (Adepoju, Salau, \& Obayelu, 2007). The principle loan repayment and the interest servicing makes the debts accrue. External indebtedness has become a ceaseless poverty aggravation mechanism, over-exploitation of work and development suppression in developing economies (Nakatami \& Herera, 2007).

While some government debts are manageable, others are not. The Greece government debt crisis started in 2009. Due to economic and other consequences, there was a severe criticism and societal reaction to the 
recovery plan. The criticism was due to skyrocketing unemployment, deterioration of public services, and slash of real income among others, which was brought about by the government policy on expenditure, closure and mergers of government institutions and dismissal of staff from the public service (Markantonatuo, 2013).

The United States of America debt surpassed 100\% gross domestic product. The anemic economic recovery, the prolonged recession and the effects of the financial crisis were brought about by the debt burden. The US debt burden started in 1970 when the government raised its expenditure without a corresponding increase in tax collection. Various aspects of government revenues and expenditures were put in place to prevent the debt burden being a US debt crisis (Thornton, 2012).

Kenya, being a developing country, depends mostly on external financing to cater for its development. Clements, Bhattacharya, \& Nguyen (2003) observed that the crowding-out effect of external debt also rose from higher debt service which increase interest cost and the budget deficit, hence reducing public savings. This lead to increase in interest rates or competition for credit available and thus crowding out private investments and dampening economic growth. Umary, Aminu, \& Musa (2013) argued that debt acquired from external sources had an unfavorable impact on the growth of the economy and that internal debt was favorable for the growth of the economy. Swamy (2015) observed that a positive effect on debt was brought about by trade openness, final consumption, expenditure and gross fixed capital formation; while a negative effect on debt was brought about by population growth, inflation, government expenditure, foreign direct investment and real GDP growth.

\subsubsection{Macroeconomic Variables}

Interest rate is the cost of acquiring, possessing and using a loan (Anyanwu \& Oaikhanam, 2005). The relationship between economic growth and interest rate in Nigeria was studied by Obamuyi (2009). He used error correction technique and cointegration and found that there was a significant outcome on economic growth and lending rate. Albu (2006) researched on the inter relationship between gross domestic product growth, investment and interest rate. He used dual partial models to check the effect of investment on gross domestic product relationship and growth between investment and interest rate in the economy of Romania. He established that investment and interest rate relationship resemble the ones exhibited in the market economy.

The price of one country's currency in terms of another country's currency is called the exchange rate (O'Sullivan \& Sheffrin, 2013). The foreign exchange therefore has the foreign currency and the domestic currency. There are different factors that affect the foreign exchange such and 
the state of a country's politics, the economy of the country, the interest rate and the exchange rate. Saheed (2015) found out that exchange rate fluctuations were explained by foreign reserve, foreign debt and debt service payment. Tille (2013) concluded that while financial flow stemming from the current account shortfall has been the primary source of the growing U.S. debt, the analysis showed that much of the recent acceleration stemmed from the appreciation of the dollar.

The International Labor Organization states that people who have no employment are those aged fifteen years and above and have used different methods of seeking employment and have found none in the last three months and were ready to start working within fifteen days. In developing countries the International Labor Organization softened the interpretation of unemployment because people who work in the family businesses are not paid and absorption in the labor market is low (Hussmann, Mehran, \& Verma, 2000). Khan, Khawar \& Khan (2014) found out that national debt reduces investment cloud, employment opportunity and economic growth. National debt reduced investment and growth and increased unemployment in Pakistan. Garcia-Jimenezi \& Mishra (2010) concluded that contrary to what most U.S. policy makers believed, debt created employment in the short run and increased public debt was detrimental to employment, the positive effect was only seen after the fourth year.

Whether the central bank can fully control money supply has been uncertain, given the problems of recurrent large fiscal deficits, relative independence of central banks, commodities booms or balance of payments problems which especially characterize African economics (Honohan \& O'Connell, 2008; Sowa, 2008). Creation of money was done by commercial banks through deposits from customers. The commercial banks used the money so deposited to give new loans. When the commercial banks issued these loans, it did not typically do so by giving reserves. A credit of the size of the bank loan is shown in their bank account. At that point, new money was created (McLeay, Radia, \& Thomas, 2014).

\subsubsection{Regulatory Reforms}

The use of revenue collected by government from taxes and payments to induce the economy is called fiscal policy. The Keynesian economics argued that when the state adjusts the rates of taxation and government expenditure, it impacts on combined demand and economic activity levels. Fiscal policy usually endeavors to maintain the economy over the period of the business cycle (O'Sullivan \& Sheffrin, 2013). Decisions and actions on monetary policy were taken by the Central Bank to establish that the money supply in the economy was compatible with price and growth goals set by the state. The aim of monetary policy was to control the stability of price in the 
economy. Price stability was attributed to sustenance of a reduced and constant inflation. According to Arestis (2007) the aspect of money being exogenous and within the dominion of central banks was shunned by many modern economists, especially the post-Keynesians. Therefore, monetary aggregates focus wass reduced in many central banks around the world. However, the opinion linger on that inflation is a monetary policy occurrence and hence the duty of central banks. Monetary policy thus has grown into prominence in macroeconomic administration and is regulated in a one instrument, one target framework (Arestis \& Sawyer, 2008).

The United States of America and the world over experienced a new financial distress in 2008. Emergency measures were taken by the US government to contain the financial system. The US reciprocated by having an array of emergency activities to fix the financial system. The economic hysteria of 2008 and the ambit of public aid needed to reduce the wave, made an excellent storm for additional financial regulation. On July 21, 2010 the US legislated the Dodd-Frank Act or the Act. Advocates of the Act praised it as a historical legislation that will trim the possibility and the degree of future financial scare, end tax payers bail outs and increase consumer protection (Guynn \& Polk, 2010). Government's use interest rate caps for various reasons such as for economic and political intentions. The government may have recognized what it contemplated to be a market breakdown in a particular industry, or that an interest rate cap is an effort to force a bigger focus of financial resources on that sector than the market would dictate. There is an argument that maximum interest rate can be legitimized on the basis of excessive profits made by financial institutions by loading enormous interest rates to clients. The Banking (Amendment) Act Laws of Kenya of 2016 fixed the maximum interest rate chargeable for a credit facility and the minimum interest earning in Kenya.

\subsubsection{Economic Growth}

Growth in the economy is the rise in the value of goods and services in the market adjusted for inflation over time by the economy. Usually it is the increase in percentage in real gross domestic product, as measured in per capita terms. The growth in the economy lead to innovation of technology and positive foreign forces (IMF 2012). Rise in investment and savings in an economy precede the economic growth (Hunt, 2007). Sachs (2002) noted that capital stock has to rise to a certain threshold before growth can start. As investment, output and capital increase, the level of savings will be enough to sustain growth. Foreign financing meant for development sustenance instead of using only internal resources is found in the dual gap theory. The theory hypothesize that investment is an action of savings and the internal savings in nations that are developing is not sufficient to supply the investment required 
to guarantee growth in the economy. It is therefore reasonable to look for complementary foreign goods and services.

Panizza \& Presbitero (2013) studied the relationship among government indebtedness and the growth of the economy in progressive economies and found that huge levels of government indebtedness had unfavorable effect on GDP and fiscal unification is needed to safeguard the expectations and build up the certainty in the economy. They also claimed that the way public debt influences progress depends on the quality of the institution, the public sector dimension, the reason for debt accumulation and the composition and structure of government indebtedness. Shah \& Pervin (2012) used OLS to investigate long and short run impact on foreign government debt and the growth of the economy in Bangladesh from 1974 to 2010. They found out that in the long period foreign debt servicing has an unfavorable effect on gross domestic product and that foreign debt has a favorable effect on GDP. There was no proof of debt overhang since there was no adverse effect on debt stock on the rise in GDP. There was still proof of crowding out effect stemming from the negative effect of servicing of debt to creditors since amassing of debt stock lead to increased debt service payment.

\subsubsection{Government Debt, Macroeconomic Variables, Regulatory Reforms and Economic Growth}

The Constitution of Kenya (2010) in Chapter Twelve on Public Finance gives Parliament the power to legislate the terms on which the government can borrow. The legal framework is given by the Internal Loans Act Cap. 420 Laws of Kenya, which gives the Cabinet Secretary for Finance authority to borrow from the local market on behalf of the government by use of Treasury bills and bonds. The target for domestic borrowing is set annually. The government is allowed to access overdraft facilities by the Central Bank Act Cap. 491 Laws of Kenya. However, only five per cent of the last audited revenue of the government can be given as overdraft as per the Act. External borrowing is governed by the External Loans and Credit Act Cap. 422 laws of Kenya; which limits the amount that can be borrowed to shillings five hundred million or such resolve by the National Assembly. Currently the country is allowed to borrow up to a limit of shillings two and a half trillion.

The main sources of external debt financing in Kenya are multilateral creditors. IDA, ADB/ADF and EEC/EIB are the main multilateral creditors. IDA is the single largest source of external resources. In terms of bilateral creditors, the main ones are Japan, France, China and Germany. China is the largest bilateral donor. Government internal debt securities involve issue of Treasury bills, treasury bonds, infrastructure bonds and pre-1997 government debt. 
Were (2011) found out that foreign debt increase has risen over the years and debt load index was on the rise. She said that Kenya's foreign debt was principally formal with a large portion coming from multilateral sources. Private investment and economic growth impacted negatively on foreign debt. Olweny \& Chiluwe (2012) found out that Treasury bill rate and government internal debt were conversely linked to investment by the private sector and that this had a positive relationship with domestic savings and the supply of money. Maana, Owino \& Mutai (2008) noted that the increase in internal debt brought about higher payment of interest presenting a big burden to the budget. They concluded that arrangement of Kenya's indebtedness has switched in support of internal debt while also expanding the debts maturity period.

Rotich, Kathanje \& Maana (2007) did a study on monetary policy reaction function for Kenya. Their study reviewed the then administration of monetary policy and the conduct of rules of CBK. They used backward and forward guidelines with suitable adjustments to take into account the attributes in countries that are developing, tested if the CBK responded to inflation changes, growth in GDP and the foreign rate of exchange in a regular and easy to foretell manner. The results pointed out that at the time of liberalization (1997-2006), monetary aggregate was used by CBK as the principal policy instrument in administering monetary policy. For the government debt to be well utilized and thereby increase the economic growth there must be some regulatory reforms. Kenya has put these regulatory reforms in the form of monetary and fiscal policies, legislation and oversight authorities such as Ethics and Anti- corruption Commission. Governments use interest rate caps for various reasons ranging from politics to economics. A market failure in an industry may have been identified by the government or a need to focus resources of financial nature on a sector of the economy are accomplished by use of interest caps as the market forces may not work. Arguments on the justification of interest ceiling on the basis that financial institution make extra ordinary profits by administering excessive rates of interest to customers. The Banking (Amendment) Act of 2016 Laws of Kenya fixed the maximum interest rate chargeable for a credit facility and the minimum interest earning in Kenya.

\subsection{Research Problem}

Kenya's domestic debt has been growing upward since independence and at the same time the external debt has also been on an upward trend (Were, 2011). The exchange rate of the Kenyan Shilling to most foreign hard currencies has been depreciating in the recent times. The Central Bank of Kenya interest rates has been increasing and unemployment has been on the rise. Inflation is high and all these have an effect on the money supply (Muthui, Kosimbei, \& Thuku, 2013). This has caused a public outcry with 
some members of the public taking the position that increased public debt is good for the economy and others saying that it is damaging the economy. This has therefore created the need for a critical literature review to ascertain the impact of government debt on economic growth.

Maana, Owino \& Mutai (2008) while investigating the internal indebtedness and its effects on Kenya's economy from 1996 to 2007, analyzed the data by use of modified barrow growth regression and established that the debt composition in Kenya changed to the advantage of internal indebtedness and there are substantial strides in the increase of the maturity profile of the indebtedness. The remarkable increases in domestic indebtedness within the period give rise to higher payments of interest presenting a big burden to the budget. Muthui, Kosimbei, \& Thuku (2013) analyzed Kenya's economic growth as impacted by national expenditure for the period 1964 to $2011 \mathrm{using}$ stationarity, causality and cointegration tests. The result showed that the expenditure by the government on education related absolutely to the economic growth though it never showed any meaningful change in growth.

\subsection{Objectives of the Study}

The main objective of the critical literature review was to review the literature done by other researchers on the impact of government debt on economic growth.

The specific objectives are:

1. To examine the impact of government debt on economic growth

2. To investigate the effects of macroeconomic variables on the relationship between government debt and economic growth.

3. To establish the effects of regulatory reforms on the relationship between government debt and economic growth.

4. To review the joint effect of macroeconomic variables and regulatory reforms on government debt and economic growth.

\subsection{THEORETICAL LITERATURE REVIEW}

\subsection{Review of Theories}

There are several theories on the indebtedness of the government and its impact on the economic growth and its effects on macroeconomic variables such as interest rates, exchange rate, unemployment, inflation and money supply. Below are the most relevant theories on government debt as put forward by different theorists.

\subsubsection{Law of Increasing State Activity}

An extensive study in relation to government spending was done by an economist from Germany known as Aldolph Wagner (1835-1917) late in the $19^{\text {th }}$ century. His study supported 'The Law of increasing State Activity'. This 
law articulates the growth of the economy and as time passes, the increase in government functions and activities. His extensive scrutiny showed that various nations had at different times indicated that industrialized nations typically increased its capability as central and local governments always initiated fresh functions, as previous and current activities are conducted with efficiency and completeness. The people's economic requirements to a large extent and in a more acceptable way are met in this manner.

His comments showed that in industrialized nations, the actions of both the local and central governments rise on a systematic basis; the broadening in state actions are both intensive and extensive; that states take fresh activities for the society's benefit; the current and previous functions are attended to with completeness and efficiency than previously; the intent of the nations' action is to contend with the peoples economic necessities; the increase and intensity of the nations' activities and functions give rise to government spending.

Adolph Wagner's law of increasing state activity seems relevant in Kenya's case as the government has continued increasing its activities especially now with both the National Government and the County Government. The expanding and increase in state social services and endeavors give rise to increased government spending. On the other hand, the theory was formulated in Germany and therefore needs to be tested if it could also apply to Kenya as the economies of Germany and Kenya are different. The theory does not also tell us where the government gets the money from to initiate fresh activities for the benefit of the society. We may not be able to say that the current and previous functions are attended to with completeness and efficiency than previously and the intent of the nation is to contend with peoples economic necessities as there has been a public outcry on the misappropriation of government funds in Kenya.

\subsubsection{The Debt Overhang Theory}

Krugman (1988) noted that there is a probability that future indebtedness will outgrow the nations' redemption capability; anticipated servicing of cost of the debt will deter any more internal and external investments as the income from the profitable investment plans will be dismal to boost the sector since remarkable part of any resulting economic development will increase to the lending country. The internal and external investments will be reduced further thereby reducing the growth of the economy (Krugman, 1988; Sachs, 1989).

Debt overhang, according to Claessens \& Diwan (1990), is a state where the effects of not being liquid, the effects of not having incentives or both are adequately intense to deter development in absenteeism of the lending country's agreement. It is a limited account of debt overhang in which the 
effects of a huge foreign indebtedness connected to deterrence in taxes discussion, and any prosperity in the borrowing nations performance in the economy is taken by the lending country and as a result very little if any remains for internal investment and resultant development (Hjertholm, 2010). The outcome of indebtedness not only touches on venturing in material capital but also any endeavor that entails obtaining expenditure in advance for the benefit of increasing production in future. Such endeavors incorporate investing in human capital and technological procurement where the effect on growth may be intense over the period (Were, 2011).

Public debt being a burden for generations to come may be the case in Kenya as it is expected that the money borrowed today will be paid latter with interest. However, it remains to be seen if public debt reduces the available lifetime consumption. This is because if the money is invested in income generating project the public debt may not reduce the available lifetime consumption. The debt overhang theory may be applied in Kenya has there is a probability that forthcoming indebtedness will outgrow the repayment capability of the country. There is need for further study to be done to verify whether the anticipated servicing of the debt expenses will deter more internal and external investment.

\subsubsection{Crowding Out Theory}

The replacement of individual financial endeavor by national financial operation endeavor is crowding out (Buiter, 1990). Crowding out reduces the individual consumption because of the increase in state spending. The rise in state spending financed by taxation decreases individual consumption. In case taxes are not increased by the state, the state turns to borrowing which entails interest rate increases and a reduction in individual investment. It is argued that increased state borrowing from the financing industry has a remarkable impact on individual borrowing and crowds out individual borrowing. Another expectation is that entry to secure state investment deters financial institutions from giving loans to high risk private sector. When the financial institutions are inhabited by lazy banks, a shilling borrowed by the government may give rise to greater than a shilling in crowding out of individual financing (Emran \& Farazi, 2009).

State expenditures are in most cases more than the revenues generated from taxes especially in states which are developing. As a result of low and developing financial markets, the state turns to external borrowing to finance the deficit in the budget. Although external debts hardly alter internal rates of interest and issue of loanable finances, there is a possibility of the effects on the cost crowding out on private capital (Beaugrand, Loko, \& Mlachila, 2012). Gray \& Woo (2010) argue that in case a deficit in the budget originated from the expenses on domestically produced items, external debt give rise to actual 
foreign rate of exchange which bring about the crowding out influence of exporters and some domestic producers. Similarly even though the cost of interest on external debt is small when compared to internal debt, there can be crowding out of individual credit because of relatively huge amount to be serviced. Were (2011) reviewed the impact of foreign indebtedness on the growth of the economy and private capital in Kenya and noted that the current investment was crowded out by the huge amount of foreign debt servicing. There is need for more studies to be done in Kenya to ascertain the actual effect of crowding out.

\subsubsection{Ricardian Equivalence Theory}

The Ricardian equivalence theorem specify that increases in state expense produce an identical growth in personal savings and a lasting impact on the real economy has no effect on the real rates of interest. The contention is that state might fund the expense by use of current taxation or acquire funds by issuing bonds. In case the government issues bonds, it finally will pay back this debt by increasing taxation more than they could have been in future. The decision has to be made on whether to tax now or in future. According to Ricardian perspective, sensible clients are mindful of the current worth of taxation in future brought about by on-going shortages, and they raise their savings consequently to fully offset the new state debt.

The Ricardian Equivalence hypothesis in which the private sector reaction counterbalances exactly the state operation might not sustain, particularly in regard to countries that are developing (Khalid, 2006). Empirical literature on the Ricardian Equivalence theorem is scarce. Additionally, the assumption of the theory of having a perfect capital market is unlikely to maintain in countries that are developing like Kenya since the capital market is not well refined. There is an assumption in the theory that consumers will offset future taxes by saving when the budget deficit is high since they are assumed to be rational. Individuals consume all their income on expenses that are current in nature and hardly save in poor economies; thereby the budget deficit has a greater likelihood of affecting the interest rates. The growth of the deficit spending increases the interest rates and therefore the Ricardian theorem may not be applicable to the Kenyan economy.

\subsection{EMPIRICAL LITERATURE REVIEW}

\subsection{Review of Empirical Studies}

\subsubsection{Government Debt and Economic Growth}

Impact of government indebtedness on the growth of the economy, unemployment and investment was studied by Khan, Khanwar, \& Khan (2014); where they analyzed data using simple regression models and ordinary 
least squares. They found out that government debt is an impediment to the growth of the economy, employment chance and investment. They also noted that government indebtedness decreases investment growth and broadens unemployment in Pakistan. Noting the straight forward as well as the response impact of national debt while analyzing the effects of external debt on Tanzania's growth, Mjema (2006) used concurrent models. He showed that the effects of financial obligation ratio to the growth in gross domestic product were unfavorable. Nonetheless the impact of foreign debt was favorable enabling a rise notwithstanding the unfavorable force is higher thereby surpassing the favorable impact of indebtedness.

Maana, Owino \& Mutai (2008) while investigating the internal indebtedness and its effects on Kenya's economy from 1996 to 2007, analyzed the data by use of modified barrow growth regression and established that the debt composition in Kenya changed to the advantage of internal indebtedness and there are substantial strides in the increase of the maturity period of the indebtedness. The remarkable increases in domestic indebtedness within the period give rise to higher payments of interest presenting a big burden to the budget.

\subsubsection{Government Debt, Macroeconomic Variables and Economic Growth}

The indebtedness of the government and what determines macroeconomics was a study done by Swamy (2015). The test was done by use of panel granger to run what determines indebtedness. He indicated that entire sample analyzed revealed the rise in gross domestic product, FDI, state expenses, inflation, and rise in population had unfavorable impression on indebtedness. The formation of gross fixed capital, expenses on final consumption had unfavorable impression on indebtedness. The formation of gross fixed capital, expenses on final consumption and openness

Nyalihama (2011) used granger causality test and cointegrated technique to analyze data from January 1995 to September 2009 while studying the determinants of money supply in Rwanda. He confirmed post Keynesian endogenous money hypothesis in the short run. He also found out that the net domestic credits to banks, net foreign assets and domestic credit to government have a significant positive influence on money and that the banking sector is a key player in money supply process and a more efficient monitoring of financial institutions is needed to ensure an efficient money supply management in Rwanda.

\subsubsection{Government Debt, Regulatory Reforms and Economic growth}

A set of reforms to boost the financial system was agreed upon in April, 2009 by the group of countries in G-20. The declaration aimed at 
having the regulatory reforms accommodate the flexibility of individual institutions and sectors (BIS 2010). To strengthen the over the counter derivatives in regard to systematic risks, a series of regulatory actions were advanced throughout the world to boost the foundation of the financial markets and increase transparency on the OTCD markets. The Dodd-Frank Act, Basel III, the Markey in Financial Instruments Directive and the European Market Infrastructure Regulation are appropriate to nations as counter parties in the OTCD transactions (OECD 2011). Sweden implemented a number of market oriented economic reforms over twenty years and its performance of the economy improved very much in comparison to other European countries (Folster, 2014).

\subsubsection{Government Debt, Macroeconomic Variables, Regulatory Reforms and Economic growth}

Umary, Aminu \& Musa (2013) noted that the outcome of the unit root suggested that all varying items in the sample that used OLS while establishing plain relation among dickey-fuller technique and variables to test unit root values and granger causation on gross domestic product, foreign indebtedness and internal indebtedness were stationery results of causality suggested a twodirection influence on foreign debt and gross domestic product with no influence on internal debt and gross domestic product. They also found out that no influence prevailed on foreign debt and internal debt. The outcome of ordinary least squares disclosed that foreign debt exhibited unfavorable effect on the growth of the economy as internal indebtedness had a favorable impact on the growth of the economy in Nigeria.

Adegbite, Ayadi, \& Ayadi (2008) used duo models in capturing nonlinear and linear relations of foreign debt in the growth of the economy while researching on the effects of foreign debt on development of the economy in Nigeria. Basing on variations of Elbadawi, Benno \& Njuguna (2007) model, he researched the effects of huge foreign debt security with its payment obligation and the result of fiscal deficit on private capital. Impact of growth in exports on the growth of GDP was proved to be statistically important. It supports Edwards (2008) affirmative assertion of growth in export process by accelerating productivity factor in Nigeria.

Amoating \& Amoaku-Adu (2009) argued that if a bigger portion of income from exports were for servicing foreign debt, growth and investment would have less foreign exchange available. This exhibits an opposite relationship on the servicing of the debt and investment growth (Gedefa, 2002). 


\subsection{Knowledge Gaps Identified from Empirical Literature Review}

In Maana, Owino \& Mutai (2008), the paper only looked at the internal indebtedness and its effect on the Kenyan economy. It neither covered external debt nor the specific factors in the economy such as the interest rates, the exchange rate, unemployment inflation and money supply. Checherita \& Rother (2010) investigated the Euro area while this critical literature review is on Kenya. They measured the effects of huge and rising national debt using GDP while this critical literature review is on the impact of government debt on economic growth and its effects on interest rates, exchange rates, unemployment, inflation and money supply. The study by Ezeabasili \& Mojekwu (2011) focused on Nigeria while this study is focused on Kenya. They analyzed the fiscal deficit while this study reviews the government debt. Investigations by Swamy (2015) used variables such as the growth of real gross domestic product, FDI, spending by the government, the growth in population and inflation among others while this review uses variables such as interest rates, exchange rate, unemployment, inflation and money supply.

Iyoha (2009) utilized macroeconometric model to assist assimilate the impact of external debt on the growth of the economy in Sub-Saharan Africa. This critical literature review looks at the impact of government debt in Kenya. Barfour (2005), while researching on Ghana, postulated that the payment of debt necessarily enforce restraint on the growth of the borrowing country's prospects as it relate to relocation of funds to different nations. To satisfactorily acknowledge the difficulty of being in debt, it is important to link the indebtedness with redemption of funds created by borrower where redemption is made. This review is different as it is done on Kenya, and focuses on debt and not debt repayment.

Herndon, Ash \& Pollin (2013) researched on whether there was any connection on government indebtedness and the growth of GDP and sought to establish if the relationship differ meaningfully by passage of time and nation. Using empirical and secondary data analysis, the study showed differing performance in growth of GDP in 20 developed countries.

\subsection{CONCLUSION AND RECOMMENDATION}

\subsection{Conclusion}

The literature review showed that there was plenty of research relating to the effect of government indebtedness on the growth of the economy. Chadha, Turner, \& Zampolli (2013) concluded that decreasing the normal maturity of United States Treasury indebtedness kept elsewhere away from the Federal Reserve by a single year is predicted to cut down the five year forward to ten year yield between one hundred and thirty and one hundred and fifty basis point. Shetta \& Kamaly (2014) concluded that as the state 
originates more instruments of debt to fund its shortfall; financial institutions change their portfolio from the personal loans that are viewed as being risky.

Maana, Owino \& Mutai (2008) concluded that the structure of Kenya's indebtedness had switched in favor of internal debt although huge progress has been in lengthening the maturity period of the debt. Muthui, Kosimbei, \& Thuku (2013) concluded that that state expenses on education was related positively to the growth of the economy without showing any notable change in growth while Njuru (2012) concluded that taxation, state expenditure, servicing of government indebtedness and reforms in finances would likewise promote or deter private capital in Kenya.

\subsection{Recommendation for other Studies}

This critical literature review sought to review the impact of government debt on the economic growth with macroeconomic variable such as the interest rates, exchange rate, unemployment, inflation and money supply being the intervening variable while regulatory reforms such as monetary policy, fiscal policy and legislation being the moderating variable. There is a need to do the actual study in Kenya with a view to get the actual impact of the government debt on the growth of the economy. The result will help in policy formulation and practice on government debt.

The researcher also recommends other studies be undertaken on the impact of government indebtedness on the economic growth with enlarged macroeconomic variables such as interest rates, exchange rates, unemployment, money supply, saving and investment; and inflation among others. This will help in getting a bigger picture of the impact of government debt on economic growth in Kenya.

Further studies may also be done on the impact of government debt on economic growth among the sub-Saharan countries and comparable results obtained to determine if they are country specific or they work across the board.

\section{References:}

1. Adegbite, E. O., Ayadi, F. S., \& Ayadi, O. F. (2008). The impact of Nigeria's external debt on economic development. International Journal of Emerging Markets, 3(3), 285-301.

2. Adepoju, A. A., Salau, A. S., \& Obayelu, A. E. (2007). The effects of external debt management on sustainable economic growth and development. Lessons from Nigeria, MPRA Paper No. 2147.

3. Albu, L. (2006). Trends in the interest rate, investment, GDP growth relation-ship. Romanian Journal of Economic Forecast., 3(1), 5-13. 
4. Amoating, K., \& Amoaku-Adu, B. (2009). Economic growth, export and external debt causality: The case of African countries, Applied Economics, 28(1), 21-27.

5. Arestis P. (2007). Is there a New Consensus in Macroeconomics? Hampshire: Palgrave Macmillan

6. Arestis, P. \& Sawyer, M. C. (2008). Re-examining Monetary and Fiscal Policy for the 21st Century. Cheltenham: Edward Elgar Publishing Ltd

7. Beaugrand, P., Loko, B., \& Mlachila, M. (2012). The choice between external and domestic debt financing budget deficits: The case of Central and West African countries. IMF Working Paper 02/79.

8. Buiter, W. H. (1990). Principles of budgetary and financial policy. Cambridge, The MIT Press.

9. Claessens, S., \& Diwan, I. (1990). Methodological issues in evaluating debt-reducing deals. WPS No. 408, May 1990. The World Bank.

10. Clements, B., Bhattacharya, R., \& Nguyen, T. Q. (2003). External debt, public investment, and growth in low-income countries. IMF Working paper 03/249.

11. Emran, M. S., \& Farazi, S. (2009). Lazy banks? Government borrowing and private credit in developing countries. Social Science Research database.

12. External Loans and Credit Act (Cap 422) Laws of Kenya

13. Ezeabasili, V. N., \& Mojekwu, J. N., (2011). Analysis of fiscal deficits and interest rates in Nigeria. Journal of Economics and International Finance, 3(4), 236-245.

14. Honohan, P. \& O’Connell, S. (2008). Contrasting monetary regimes in Africa In M Ncube (Fds), Financial systems in monetary policy in Africa 102-119). Nairobi African Economic Research Consortium.

15. Hussmanns, R., Mehran, F., \& Verma, V. (2000). Surveys on economically active population: An ILO manual on concepts and methods, ILO, Geneva.

16. Internal Loans Act (Cap 420) Laws of Kenya

17. Khalid, A. (2006). Ricardian Equivalence: Empirical Evidence from Developing Economies. Journal of Development Economics, 51(2), 413-432.

18. Khan H., Khawar M., \& Khan, I. (2014). Effect of public debt on economic growth, investment and unemployment. Academic Research International, 3(2), September, 2014

19. Krugman, P. (1988). Financing vs. forgiving a debt overhang: Some analytical issues. NBER Working Paper No. 2486. 
20. Likita, T. (2010). Fertilizer subsidy policy: Implications for investment in the agricultural sector. The Nigerian Journal of Economic and Social Studies, 42(3), 401-410.

21. Maana, I., Owino, R., \& Mutai, N. (2008). Domestic debt and its impact on the economy - The case study of Kenya. Paper presented during the $13^{\text {th }}$ Annual African Econometric Society in Pretoria, South Africa from $9^{\text {th }}$ to $11^{\text {th }}$ July, 2008.

22. Markantonatuo, M. (2013). Diagnosis, treatment, and effects of the crisis in Greece: A "Special Case" or a "Test Case"? MPIG Discussion Paper 13/3 Max Planck Institute for the Study of Societies, Cologne, February 2013.

23. McLeay, M., Radia, A., \& Thomas, R. (2014). Money creation in the modern economy. Bank of England Quarterly Bulletin, 2014 Q1.

24. Mjema, G. D. (2006). The impact of foreign debt servicing in the economy of Tanzania: A simultaneous equation approach. African Journal of Economic Policy, 3(1), 5-23.

25. Muthui, J. N., Kosimbei, G., \& Thuku, G. K. (2013). The impact of public expenditure components on economic growth in Kenya, 19642011. International Journal of Business and Social Science, 4(4), 151159.

26. Nakitami, K., \& Herera, J. (2007). The endogenous money supply: Consensus and disagreement. Journal of Post Keynesian Economics. 13(3), 397-403.

27. Nyalihama C. (2011). Determinants of money supply in Rwanda (1995-2009) (Doctoral dissertation, University of Nairobi). Available from University of Nairobi Digital Repository.

28. Olweny, T., \& Chiluwe, M. (2012). The effect of monetary policy on private sector investment in Kenya. Journal of Applied Finance and Banking; 2(2), 239-287.

29. O'Sullivan, A., \& Sheffrin, S. M. (2013). Economics: Principles in action. Upper Saddle River, New Jersey 07458: Pearson Prentice Hall.

30. Panizza, U., \& Presbitero, A. F. (2013). Public Debt and Economic Growth in Advanced Economies: A Survey. Money and Finance Research Group Working Paper no. 78, January 2013.

31. Rotich, M., Kathanje, K. \& Maina. N. (2007). A monetary policy reaction function for Kenya, Unpublished paper, KIPPRA

32. Sachs, J. D. (2002). Resolving the Debt Crisis of Low Income Countries. Brooking Papers on Economic Activity 2002, pp1-28.

33. Saheed, Z. S. (2015). Impact of public external debt on exchange rate in Nigeria. International Finance and Banking, 2(1), 2074-2089. 
34. Shah, M., \& Pervin, H. (2012). External Public Debt and Economic Growth: Empirical Evidence from Bangladesh, 1974 to 2010. Academic Research International, 3(2), 78-100.

35. Swamy, V. (2015). Government debt and its macroeconomic determinants: An empirical investigation. IEG Working Paper No. 362.

36. Thornton, D. (2012). The US deficit/debt problem: A longer-run perspective. Federal Reserve Bank of St. Louis Review, November/December 2012, 94(6), 441-55.

37. Tille, S. (2013). The impact of exchange rate movement on U.S. foreign debt. Current Issues in Economics and Finance, 9(1), 324-35.

38. Umary, A., Aminu, A., \& Musa, S. (2013). External debt and domestic debt impact on the growth of the Nigerian economy. International Journal of Educational Research, 1(2). 2306-2323.

39. Were, M. (2011). The impact of external debt on economic growth and private investment in Kenya: An empirical assessment. WIDER Discussion paper No 2001/116; United Nation University. 